\title{
Disease-age Correlated Study of Some Patients with Solitary Hypertension Attending Central Hospital, Benin City, Nigeria
}

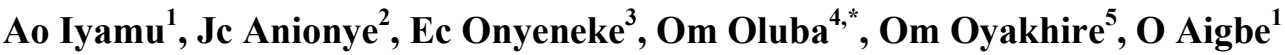 \\ ${ }^{1}$ Department of Medical Biochemistry, College of Medicine, Ambrose Alli University, Ekpoma, Nigeria \\ ${ }^{2}$ Department of Medical Biochemistry, College of Medicine, University of Benin, P.M.B. 1154,Benin City, Nigeria \\ ${ }^{3}$ Department of Biochemistry, Faculty of Life Sciences, P.M.B. 1154, Benin City, Nigeria \\ ${ }^{4}$ Department of Biochemistry, College of Natural Sciences, Joseph Ayo Babalola University, Ikeji-Arakeji, Osun State, Nigeria \\ ${ }^{5}$ Department of Human Anatomy, University of Portharcourt, Porthacourt, Nigeria
}

\begin{abstract}
The study was aimed at verifying how oxidative status varies with age of diabetes mellitus (DM) in sufferers with adequate blood sugar control. Forty-one diabetic otherwise healthy (DOH) volunteers and 57 apparently healthy controls were used and plasma levels of two endogenous antioxidant enzymes (Superoxide dismutase, SOD, and catalase, CAT) as well as two markers of oxidative damage (Malondialdehyde, MDA and erythrocyte osmotic fragility, EOF) were determined. Results obtained showed significant decreases in plasma SOD and CAT activities, and significant increases in plasma levels of MDA and EOF as age of disease increases. In addition, there were clear significant differences between the oxidative status of DOH and apparently healthy control subjects of similar chronological (birth) age group. Plasma MDA and EOF as markers of oxidative damage were significantly higher in DOH subjects compared with healthy control subjects of similar age. However, plasma SOD and CAT activities were observed to be significantly lower in DOH subjects compared with healthy control subject of comparable age. It could thus be concluded that diabetes is associated with progressive increase in tissue oxidative damage.
\end{abstract}

Keywords Solitary Hypertension, Reactive Oxygen Species, Disease - Age, Hypertensive Otherwise Healthy

\section{Introduction}

The imbalance between the generation of reactive oxygen species (ROS) and the counteracting oxidant defenses, called oxidative stress is closely associated with a number of disease conditions particularly those of cardiovascular and metabolic origin. Hypertension, a state of sustained elevation of blood pressure beyond $140 / 90 \mathrm{mmHg}$, and its complications have a causal relationship with oxidative stress. The generation of reactive (oxygen or nitrogen) species by various enzymatic and non - enzymatic mechanisms is the cause of this stress situation. The destruction or inactivation of the various antioxidant systems may also yield an unfavorable oxidative status.

Oxidative stress has been defined as excess formation and/or insufficient removal of highly reactive molecules such as reactive oxygen or nitrogen species (ROS or RNS)[1]. The amounts of ROS and RNS in plasma are, in

* Corresponding author:

olubamike2000@yahoo.co.uk (Om Oluba)

Published online at http://journal.sapub.org/ajb

Copyright (C) 2012 Scientific \& Academic Publishing. All Rights Reserved part, dependent on the activities of ROS - generating enzymes and their modulators. Such enzymes include nitric oxide synthase (NOS)[2], NAD(P)H oxidase[3] xanthine oxidase[4], phospholipase $A_{2}$ and other enzyme involved in lipid metabolism including lipoxygenase (LOX) and cyclooxygenase (COX) [5]. A novel agent, asymmetric dimethylarginine (ADMA), which inhibits NOS by competing with $\mathrm{L}$ - arginine, the substrate for the enzyme, is found in elevated amounts in hypertension[4].

As the rate of ROS formation increases, the rate of its pathological consequences also increase including vascular remodeling, lipid peroxidation, protein oxidation, etc[6]. Increased vascular ROS itself may induce endothelial NOS uncoupling as a consequence of increased oxidation of tetrahydrobiopterin and inhibition of dimethyl - arginine dimethyl - amino hydrolase (DDAH), the hydrolyzing enzyme of ADMA[7]. ADMA levels positively correlate with age and mean arterial pressure[8]. The activity of NAD $(\mathrm{P}) \mathrm{H}$ oxidase is also modulated by ADMA. There is evidence that xanthine oxidase, which generates superoxide radical is involved in the pathogenesis of hypertension[4].

Endogenous Nitric oxide (NO) plays an important role in the regulation of blood pressure. This regulatory role is 
evident in the hypertension that occurs when the endogenous production of NO is prevented by blockade of NOS, the enzyme that produces NO. Nitric oxide (NO) of endothelial origin, normally maintains vascular smooth muscle in a particularly relaxed state. When endogenous $\mathrm{NO}$ is eliminated, additional contraction of vascular smooth muscle occurs, resulting in an increase in vascular resistance and elevation of blood pressure[9]. Wei et al[10] proposed that "superoxide and other radicals interfere with acetylcholine induced endothelium - dependent vasodilation, probably because they destroy the endothelium - derived relaxant factor. This relaxant factor was later established to be NO[11].

Gryglewski et al[12] observed that the stability of NO was markedly increased by the treatment with superoxide dismutase (SOD). The reaction of $\mathrm{NO}$ and $\mathrm{O}_{2}{ }^{-}$results in the formation of peroxynitrate $\left(\mathrm{ONOO}^{-}\right)$which is also a vasorelaxant but with a shorter half life and less potency than NO[13,14].Treasure et al[15] have reported a deficit in endothelial NO released in several vascular beds in human hypertension. In another study by Moro et al[13] it was found that during hypertension there is in the endothelial cells an excess of superoxide radicals $\left(\mathrm{O}_{2}^{-}\right)$that scavenges $\mathrm{NO}$ as it is produced.

Several indicators exist for the state of oxidative stress. This may include, among others, levels of endogenous enzymes such as catalase (CAT) and SOD[16]. Malondialdehyde (MDA), a product of lipid peroxidation, is used as an indicator of oxidative stress in cells and tissues[17,18]. Erythrocyte osmotic fragility defines the integrity of cell membranes, a major site of lipid peroxidation and protein oxidation. It thus indicates the stability and functionality of plasma membranes[19]. This study aims to see whether there is any definable pattern in the variation of oxidative status with disease age in sufferers of solitary hypertension with consistently well - controlled blood pressure. This is expected to underpin the importance of tissue oxidation - reduction in hypertension, as distinct from the elevated blood pressure, in the pathogenesis, progression and complication of the disease.

\section{Materials and Methods}

\section{Reagents}

All chemicals and reagents used are Analar grade and are either products of either BDH Chemical Limited (Poole, England or Randox Laboratories Limited (USA) unless otherwise stated.

\section{Sample Population}

Volunteer Hypertensive patients without any other chronic medical condition ( $\mathrm{n}=56 ; 23$ males and 33 females) and regularly attending the medical out - patient clinic of the Central Hospital were used for this study. The duration of the hypertension in the patient was taken as the "disease age" and the patients' health status was written as $\mathrm{HOH}$ meaning "Hypertensive, otherwise healthy". Inclusion Criteria include: clinically confirmed hypertension (BP $\geq 140 / 90$ mmHg persistently);

Age of hypertension of at least one year; chronological (birth) age of both hypertensive and control volunteers of at least 20 years; and evidence of antihypertensive drug compliance and documented values of regular blood pressure check consistently lower than 140/90 mmHg. Patients were excluded from the study on the following basis: blood transfusion within the last 3 months years; intravenous fluid management in the last $24 \mathrm{hrs}$, patient's refusal.

\section{Blood collection}

After consent was obtained from both patient and institution (hospital management) blood samples were obtained from each patient in heparinized bottles and frozen in the refrigerator at $40 \mathrm{C}$ before used. A maximum of two freeze / thawing cycles was allowed since three or more cycles modify the oxidative status of the blood[20] and storage increases the levels of the markers of oxidative damage[21]. The plasma was assayed for superoxide dismutase activity, catalase activity and malondialdehyde (MDA) level.

\section{Preparation of Erythrocyte (Blood Tissue) Samples}

The erythrocytes were washed by centrifugation method as described by Tsakiris et al.[22]. The samples were introduced into centrifuge test tubes containing $3.0 \mathrm{mls}$ of buffer solution ( $\mathrm{pH}=7.4$ ) of $250 \mathrm{mM}$ Tris (hydroxlmethyl) amino - ethane - $\mathrm{HCl}$ (Tris $\mathrm{HCl}$ ), $140 \mathrm{mM} \mathrm{NaCl}, 1.0 \mathrm{mM}$ $\mathrm{MgCl}_{2}$ and $10 \mathrm{mM}$ glucose. The suspension was centrifuged at $120 \mathrm{~g}$ for $10 \mathrm{~min}$ to separate the erythrocytes from the liquid phase. After centrifugation, the supernatant was carefully withdrawn with Pasteur pipette and decanted. The sediment constituted harvested erythrocytes. The erythrocytes were re - suspended in the buffer and washed three times by similar centrifugation technique. The erythrocytes were finally suspended in $1 \mathrm{ml}$ of this buffer solution.

\section{Estimation of Malondialdehyde (MDA) Level}

The extent of lipid peroxidation was determined spectrophotometrically by thiobarbituric acid reactive substances (TBARS) method as described by Varshney and Kale[23]. Results were expressed in terms of malondialdehyde (MDA) formed per mg protein. MDA, a product of lipid peroxidation (TBARS) under acid conditions forms a pink colored product that has a maximum absorbence at $532 \mathrm{~nm}$.

\section{Determination of Erythrocyte Osmotic Fragility}

Erythrocyte fragility was determined by a slight modification of the blend of the methods of Kraus et al.[24] as modified by Karabulut et al.[25]. In principle erythrocyte membranes undergo lysis when erythrocytes are suspended in a $\mathrm{NaCl}$ solution with concentration of $\mathrm{NaCl}$ less than the physiological concentration (about $0.8-0.9 \%$ ). Haemoglobin released when the cells are haemolysed, absorbs maximally at $450 \mathrm{~nm}$. The optical density increased with the amount of cells haemolysed and hence the amount of haemoglobin 
released.

\section{Assay of Superoxide Dismutase (SOD, EC. 1.15.1.1)}

SOD activity was determined using adrenaline as a substrate according to the method described by Fridovich[26] and was expressed as enzyme unit/mg protein. One unit of enzyme is defined as the amount required for $50 \%$ inhibition of adrenaline auto oxidation.

\section{Determination of Catalase (CAT, EC. 1.11.1.1) activity}

The method of Goth[27] was followed in the determination of serum CAT activity. The procedure is based on the ability of CAT to convert hydrogen peroxide to water and oxygen. Catalase activity (level) is the rate at which it causes the disappearance of the substance $(\mathrm{H} 2 \mathrm{O} 2)$. Briefly, aliquots of the blood $(0.5 \mathrm{ml})$ were added into ice cold test tubes while the blank contained $0.5 \mathrm{ml}$ distilled water. The reactions were initiated by adding sequentially, at fixed intervals, $5 \mathrm{ml}$ of cold $30 \mathrm{mM}$ of $\mathrm{H} 2 \mathrm{O} 2$ and were mixed thoroughly by inversion. After exactly 3 minutes, the reaction was stopped sequentially at the same fixed intervals by rapidly adding $1 \mathrm{ml}$ of $6 \mathrm{M}$ of $\mathrm{H} 2 \mathrm{SO} 4$ and was mixed quickly by inversion and of absorbance of $480 \mathrm{~nm}$, read within $30-60$ seconds. The spectrophotometer standard was prepared by adding $7 \mathrm{ml}$ of $0.01 \mathrm{M}$ potassium permanganate to a mixture of $5.5 \mathrm{ml} 0.5 \mathrm{M}$ phosphate buffer, $\mathrm{pH} 7.0$ and 1 $\mathrm{ml} 6 \mathrm{M} \mathrm{H} 2 \mathrm{SO}$. The enzyme activity was expressed in terms of "Kat.f" as Ks-1mg-1 protein, where $\mathrm{K}$ is the first order rate constant.

\section{Protein determination}

Protein was determined by the Biuret method as described by Gornall et al[28] using bovine serum albumin (BSA) as standard.

\section{Statistical Analysis}

The parametric single factor analysis of variance
(ANOVA) was used in testing for significant differences in the indices of oxidative status among the various $\mathrm{DOH}$ treatments while student's t-test was used in testing the significant differences between healthy control and $\mathrm{DOH}$ subjects. Where significant differences $(\mathrm{P}<0.05, \mathrm{P}<0.01$, $\mathrm{P}<0.001)$ were detected by ANOVA and student's t-test, the aposterior Duncan Multiple range test was used to locate the source(s) of significant difference(s) among the treatments[29]. All statistical tests were carried out using SPSS version 17.0.

\section{Results}

Plasma MDA level was significant $(\mathrm{p}<0.001)$ elevated in hypertensive but otherwise healthy $(\mathrm{HOH})$ subjects within the ages of $11-20$ years compared with the levels observed in subjects under 11 years and those above 20 years (Table 1). There was no significant chage in plasma MDA observed in subjects under 11 years and those above 20 years. Blood EOF values were not significantly altered within the three age range grouping in $\mathrm{HOH}$ subjects. Similarly, plasma SOD activity was not significantly changed in $\mathrm{HOH}$ subjects within the three age groupings. Significantly $(p<0.05)$ higher activity was observed in CAT acivity in $\mathrm{HOH}$ subjects within 11-20 years old compared to $\mathrm{HOH}$ subjects within 0-10 and 21 years and above (Table 1). Table 2 showed a comparative analysis of plasma MDA, EOF, SOD activity and CAT activity between normal control and $\mathrm{HOH}$ subjects of comparable age. Plasma MDA showed a significant increase $(\mathrm{p}<0.001)$ in $\mathrm{HOH}$ group comparared to control. Similarly, plasma EOF was significantly higher $(\mathrm{p}<0.001)$ in $\mathrm{HOH}$ group compared with control. Similarly, plasma SOD and CAT activities were significantly lower $(\mathrm{p}<0.001)$ in $\mathrm{HOH}$ group compared with control.

Table 1. Age of diabetes otherwise healthy $(\mathrm{HOH})$ volunteers

\begin{tabular}{|c|c|c|c|c|}
\hline Parameter & $1-10$ yrs & $11-20$ yrs & 21 yrs $\&$ above & P-value \\
\hline MDA (nmolmg-1 protein) & $2.87 \pm 0.16^{\mathrm{a}}$ & $4.77 \pm 0.38^{\mathrm{b}}$ & $3.22 \pm 0.56^{\mathrm{a}}$ & $\mathrm{P}<0.01$ \\
\hline EOF (x100\% Haemolysis) & $0.41 \pm 0.01^{\mathrm{a}}$ & $0.44 \pm 0.01^{\mathrm{a}}$ & $0.44 \pm 0.03^{\mathrm{a}}$ & $\mathrm{P}>0.05$ \\
\hline SOD (Umg-1 ${ }^{-1}$ protein) & $11.12 \pm 0.12^{\mathrm{a}}$ & $10.83 \pm 0.14^{\mathrm{a}}$ & $11.04 \pm 0.21^{\mathrm{a}}$ & $\mathrm{P}>0.05$ \\
\hline CAT $\left(\mathrm{Umg}^{-1}\right.$ protein) & $5.12 \pm 0.17^{\mathrm{a}}$ & $3.79 \pm 0.09^{\mathrm{b}}$ & $4.17 \pm 0.67^{\mathrm{a}}$ & $\mathrm{P}<0.05$ \\
\hline
\end{tabular}

Note: Similar letters indicate mean that are not significantly different from each other

$\mathrm{P}<0.0$ - Highly significant

$\mathrm{P}<0.05$ - Significant

$\mathrm{P}>0.05$ - Not significant

$\mathrm{HOH}-H y p e r t e n s i v e$ otherwise Healthy

Table 2. Comparison of the means of the various indices in $\mathrm{HOH}$ and healthy controls of similar chronological (birth) age groups

\begin{tabular}{|c|c|c|c|}
\hline Parameter & Control & HOH & P-value \\
\hline MDA (nmolmg-1 protein) & $1.72 \pm 0.08$ & $3.07 \pm 0.16$ & $\mathrm{P}<0.001$ \\
\hline EOF (X 100\% Haemolysis) & $0.36 \pm 0.01$ & $0.42 \pm 0.01$ & $\mathrm{p}<0.001$ \\
\hline SOD (Umg-1 protein) & $14.36 \pm 0.11$ & $11.08 \pm 0.10$ & $\mathrm{P}<0.001$ \\
\hline CAT (Umg-1 protein) & $6.87 \pm 0.22$ & $4.90 \pm 0.16$ & $\mathrm{P}<0.001$ \\
\hline
\end{tabular}

Note: Similar letters indicate mean that are not significantly different from each other.

$\mathrm{P}<0.001$ - Highly significant

$\mathrm{HOH}$ - Hypertensive otherwise Healthy 


\section{Discussion}

Oxidation - reduction reaction occur in the human body system. Several physiological and pathological events occurs that impact on the overall health status the cumulative effects of several of these physiological events lead to accumulation of free radicals with advancing age with both cover and overt manifestations such as increasing levels of lipid peroxides, alteration in enzyme activities and greater osmotic fragility[30]. The erythrocyte osmotic fragility has been previously studied in healthy young and elderly subjects as well as in sufferers of hypertension[31-32].

Though no significant difference was observed in mean SOD and MDA levels as the age of hypertension increases in $\mathrm{HOH}$ subject, significant differences were observed when these subjects $(\mathrm{HOH})$ were matched with apparently healthy control subjects of similar ages thus suggesting a causal effect of hypertension in modulating plasma oxidative status.

Our findings are consistent with those of Redon et al[33] that circulatory levels of MDA are significantly higher in hypertensive subjects than in normotensive controls and that there are significantly lower activities of SOD and catalase in hypertensives. It is also consistent with the findings of Fasanmade[34] who had earlier reported that erythrocyte osmotic fragility is significantly elevated in hypertensives than in normotensives. Accentuation of oxidative stress results when ageing coexist with hypertension. This is corroborated by Akila et al[30] who reported an increased rate of lipid peroxidation with a corresponding decrease in antioxidants status in elderly hypertensive subjects.

The observed increase in MDA and EOF levels as markers of oxidative damage -could be attributed to the observed decrease in activities of the antioxidant enzymes, SOD and CAT[35]. This indicates that any plausible attempt to delay complications of hypertension could as well decrease the activities of antioxidant enzymes. This is strongly contradictory to the assertion made from some studies[36] that there is no health benefit of taking antioxidants.

Results from this study suggest that hypertension results in more oxidative damage than would have been expected under normal situation. This accounts for the decrease in activities of antioxidant enzymes (SOD and CAT) and increase in markers of blood oxidative damage (MDA and EOF). Despite the fact that blood pressures of the subjects used for this study were consistently well - controlled the imbalance in oxidative status in $\mathrm{HOH}$ was found to exceed that under normal conditions of graceful ageing. This suggests that other factors exist apart from the elevated blood pressure, that disrupts oxidative balance and precipitate development of complications. Reactive oxygen species appear to account for a significant part of these factors. The findings here do not provide supportive evidence for the Mitohormesis model of Ristow and Zarsek[37] that undermines the health benefit of antioxidant supplementation and debunks the oxidative stress theory of ageing and disease complications.

\section{REFERENCES}

[1] U. Forstermann, and E. I. Closs, "Nitric oxide synthase isozymes: characterization, purification, molecular cloning, and function," Hypertension, 23, 1121 - 1131

[2] Touyz, R. M., Chen, X., Tabel, F., Yeo, G., He, G., Quinn, M. J., Pagano, P. J., and Schiffrin, E. L., 2002, Expression of a functionally active gp91phox - containing neutrophil - type NADPH oxidase in smooth muscle cells from human resistant arteries regulation by Angiotensin II., Circ Es., 9: 1205 - 1213

[3] Suzuki, H., Delano, F. A., Parks, D. A., Jamshichi, N., Granger, D. N., Ishii, H., Suematsu, M., Zwefach, B. W., and Shnard - Shonbein, G. W., 1998, Xanthine Oxidase activity associated with arterial blood pressure in spontaneously hypertensive rats., Proct Nat Acad Sci USA, 95: 4754 - 4759

[4] Edderkavni, M., Hing, P., Vanguero, E. C., Lee, J. K., Fischor, L., Fries, H., Burchler, M. W., Lerch, M. M., Pandol, S. J., and Gukoshaya, A. S., 2005, Extracellular matrix stimulates reactive oxygen species production and increases pancreatic cancer cell survival through 5 - lipoxygenase and NADPH oxidase., Am J Physiol Gastrointestinal Liver Physiol., 289: G1137 - 1147

[5] Atalay, V. P., Harishchandra, H., D'Souza, V., and D'Souza, B., 2007, Age - related changes in Lipid peroxidation and antioxidants in elderly people., Ind J Cli. Biochem., 22(1):131 $-134$

[6] Wider, J. D., Guzik, T. J., Mueller, C. F., Clempus, R. E., Schmidt, H. H., Dikalor, S. I., Griendling, K. K., Jones, D. P., and Harrison, D. G., 2007, Role of the multidrug resistant protein - I in hypertension and vascular dysfunction caused by Angiostensin II., Arterioscl Thromb Vasc Biol., 27: 762 768

[7] Kimura, S., Zhang, G. X., Nishiyama, A., Shokoji, T., Yao, L., Fan, Y. Y., Rahman, M., and Abe, Y., 2005, Mitochondria derived reactive oxygen species and vascular MAD kinases comparison of Angiostensin II nitric oxide., Hypertension, 45: $438-444$

[8] Ribeiro, M. O., Antunes, E., de Nucci, G., Lovisolo, S. M., and Sats, R., 1992, Chronic inhibition of nitric oxide synthesis: a new model of arterial hypertension., Hypertension, 20: 298 $-303$

[9] Wei, E. P., Kantos, H. A., Christman, C. W., De Witt, D. S., and Porlish, J. T., 1985, Long term cardiovascular role of nitric oxide in conscious rats., Circ Res., 57: 781 - 789

[10] Palmer, R. M. J., Ferrige, A. G., and Moncada, S., 1987, Nitric oxide release account for the biological activity of endothelium - derived relaxing factor., Nature, 327: 524 - 526

[11] Gryglewski, R. J., Palmer, R. J., and Moncada, S., 1986, Superoxide anion is involved in the breakdown of endothelium - derived vascular - relaxing factor., Nature, $320: 454-456$

[12] Moro, M. A., Darley - Usmar, V. M., Goodwin, D. A., Read, N. G., Zamora - Pino, R., Feelisch, M., Radmski, M. W., and Moncada, S., 1994, Paradoxical fate and biological action of peroxynitrite in human platelets., Proc Nat Acad Sci USA, 91: $6702-6706$ 
[13] Liu, S., Beckan, J. S., and Ku, D. D., 1994, Peroxynitrite, a product of superoxide and nitric oxide, producing coronary vasorelaxation in dogs., J Pharmacol Exp Ther., 268:1114 1121

[14] Treasure, C. B., Manoukian, S. V., Klein, J. L, Cita, J. A., Renwick, G. H., Selwyn, A. P., Alexander, R. W., and Ganz, P., 1992, Epicardial coronary artery response to acetylchlorine are impaired in hypertensive patients., Circ Res., 71: 778 - 781

[15] Wassman, S., Wassman, K., and Nikenig, G., 2004, Modulation of oxidant and antioxidant enzyme expression and function in vascular cells., Hypertension, 44: 381 - 386

[16] De - Duve, C., 1978, A re-examination of the physiological role of peroxisomes in: Tocopherol, oxygen and biomembrane (ed. C. De - Duve and O. Hayaishi). Elsevier/North Holland Biomedical Press Amsterdam., pp $351-31$

[17] Kilic, E., Yazar, S., Saraymen, O., and Ozblige, H., 2003, Serum malondialdehyde level in patients infected with Ascaris Lumbricoides., World J Gastroenterol., 9: 2332 2334

[18] Romero, F. J., Bosch - Morell, F., Romero, M. J., Jareno, E. J., Romero, B., Marin, N., and Roma, J., 1998, Lipid peroxidation products and antioxidants in human disease., Environ Health Perspectives, 106: 1229 - 1234

[19] Krogmeier, D. E., Mao, I. L., and Bergen, W. G., 1993, Genetic and non - genetic effects of erythrocyte osmotic fragility in lactating Holstein cows and its association with yield traits., J Dairy Sci., 76: 1994 - 2000

[20] Kampa, M., Nistikaki, A., Tsousis, V., Maliaraki, N., Notas, G., and Castanas, E., 2002, A new automated method for the determination of the total antioxidant capacity (TAC) of human plasma based on the crocin bleaching assay., BMC Clin Pathol., 2:3

[21] Oyewale, J. O., Sanni, A. A., and Ajibade, H. A., 1991, Effects of temperature, $\mathrm{pH}$, and blood storage on osmotic fragility of duck erythrocytes., Zentralblatt fur veternamedizin, 38(4): $261-264$

[22] Tsakiris, S., Giannoulia - Karantana, A., Simintzi, I. H., and Schulpis, K. H., 2005, The effect of aspartame metabolites on human erythrocyte membrane acetylcholinesterase activity., Pharmacol Res., 53: 1 - 5

[23] Varshney, R., and Kale, R. K., 1990, Effects of calmodulin antagonists on radiation-induced lipid peroxidation in microsomes., Int J Rad Biol., 58: 733-743

[24] Kraus, A., Roth, H. P., and Kirchgessner, M., 1997, Supplementation with Vitamin C, Vitamin E, or $\beta$-Carotene influences osmotic fragility and oxidative damage of erythrocytes of Zinc - deficient rats., J Nutr., 127:1290 - 1296
[25] Karabulut, I., Dicle-Balkanci, A., Pehlivanoglu, B., Erdem, A., and Fadillioglu, E., 2009, Deprivation of drinking water up to 48 hours does not affect the osmotic fragility of erythrocytes from captive helmeted guinea fowl (Numida Mealagris)., Tox Industr Health, 25:545 - 550

[26] Fridovich, I., 1989, Superoxide dismutase. An adaptation to a pragmatic gase., J Bio. Chem., 264: 7762-7764

[27] Goth, L., 1991, A simple method for the determination of serum catalase activity and revision of reference range., Clin Chem Acta, 196:143 - 152

[28] Gornall, A. G., Baradawill, C. J., and Maxima, D., 1949, Determination of serum proteins by means of the Biuret reaction., Biol Chem., 177: 751-766

[29] Ogbeibu, E. A., 2005, Biostatistics: A practical approach to research and data handling. Mindex publishing Co. Ltd., Benin City, Nigeria, Pp 171 - 173

[30] Akila, V. P., Harishandra, H., D'Souza, V., and D'Souza, B., 2007, Age related changes in lipid peroxidation and antioxidants in elderly people., Ind J Clin Biochem., 22(1):131 - 134

[31] Ward, W. C., Hodgson, J. M., Puddy, I. B., Mori, T. A., Beiling, L. J., and Croft, K. D. C., 2004, Oxidative stress in human hypertension: association with antihypertensive treatment, gender, nutrition and lifestyle., Free Rad Biol Med., 36: $226-232$

[32] Simic, D. V., Mimic - Oka, J., Pljesa - Ercegovac, M., SaviRadojevic, A., Opacic, M., Ivanovic, D. M. B., and Simic, T., 2006, Byproducts of oxidative protein damage and antioxidant enzyme activities in plasma of patients with different degrees of essential hypertension., J Human Hypertension, 20: 149 - 155

[33] Redon, J., Oliva, M. R., Tormos, C., Giner, V., Chares, J., Iradi, A., and Saez, G. T., 2003, Antioxidant activities and oxidative stress byproducts in human hypertension, Hypertension, 41: 1096 - 1101

[34] Fasanmade, A. A., 1984, Erythrocyte osmotic fragility in hypertension and during diuretic therapy., West Afr J Med., 18(3): $183-186$

[35] Gryglewski, R. J., Palmer, R. J., and Moncada, S., 1986, Superoxide anion is involved in the breakdown of endothelium - derived vascular - relaxing factor., Nature, $320: 454-456$

[36] Ristow, M., and Zarse, K., 2010, How increased oxidative stress promotes longevity and metabolic health: the concept of mitochondrial hormesis (mithormesis)., Exp Gerontol., 45:410 - 418

[37] Anghel, S. A., 2010, Antioxidant not heaven - sent., Harv Sci Rev., 32 - 34 